\title{
Performance and Macrophage Activity of Broilers Fed with a Sorghum Meal with Different Yeast Wall Levels
}

\author{
Suelen Regina Ferreira ${ }^{1 *}$, Alice Eiko Murakami ${ }^{2}$, Thais Gomes Verzignassi Silveira ${ }^{2}$, José \\ Maurício Gonçalves dos Santos ${ }^{3}$ and Jovanir Inês Muller Fernandes ${ }^{4}$ \\ ${ }^{I}$ Médica Veterinária Autônoma; Maringá - PR - Brasil. ${ }^{2}$ Universidade Estadual de Maringá; Maringá - PR - Brasil. \\ ${ }^{3}$ Centro Universitário de Maringá; Maringá - PR - Brasil. ${ }^{4}$ Campus Palotina; Universidade Federal do Paraná; \\ Palotina - PR - Brasil
}

\begin{abstract}
The aim of this work was to evaluate the effect of broiler breeders' age and yeast wall (YW) levels on broilers' performance and macrophage activitys. The experiment consisted in a completely randomized design and a $2 X 5$ factorial arrangement and two controls of two broiler breeders age (34 and 57 weeks of age) and five YW levels (zero, one, two, three or four $\mathrm{kg}$ of $Y W /$ ton of diet). They received sorghum diet compared to a control corn/soybean meal diet. The age of the broiler breeders influenced the performance, but did not affect macrophage activity. At 34 weeks age broiler breeders' progeny, all diets were similar considering the average weight. For 57 weeks age broiler breeders' progeny, at 21 days, only average weight of sorghum diet supplemented with $4 \mathrm{~kg} / \mathrm{ton}$ was similar to corn diet results. The optimum level of YW for maximal macrophage activity was $2.06 \mathrm{~kg} / \mathrm{ton}$ of meal.
\end{abstract}

Key words: carcass yield, mananoligossacarydes, phagocytosis

\section{INTRODUCTION}

The poultry production is a dynamic activity that involves many areas, which depend on the technological innovations for results in field improvement, such as weight gain, feed conversion, or egg production. It is a complex chain that transforms the one-day old chicken, weighing about $42-45 \mathrm{~g}$ to broiler chickens weighing $2.1-2.5 \mathrm{~kg}$ at 42 days. This fast production of meat depends on genetic, environment, nutrition, and health status. These factors are interdependent among which nutrition and health status are basic factors to attain the productivity goals. Several studies have been conducted for better understanding of the physiological necessities of the birds to obtain performance indices and the physiology of the immune system, inclduing under adverse sanitary conditions (Qureshi et al., 1994; Ferket et al., 2002; Soares, et al., 2004; Pucciarelli and Benassi, 2005; Leblanc, et al., 2006).

Studies have been made on developing the products and/or substances that act as modulators and/or stimulators of the immune system for the birds, for examples, the manna oligosaccharides and the B-glucan, derived from the yeast cellular wall (Leblanc, et al., 2006). The macrophages, acting in the innate immunity, through the destruction of pathogens agents and adaptative antigens presentation (Qureshi, 2003; Abbas et al., 2007) are an important defense mechanism of the

*Author for correspondence: suelenrf@ hotmail.com 
birds. Related studies on the function of these cells add important knowledge on the immune response of the birds (Qureshi et al., 1994).

The objective of this study was to evaluate the effect of increasing levels of yeast wall on the growth performance and the fagocytic activity of macrophages of the broilers fed with sorghum diets instead of corn.

\section{MATERIAL AND METHODS}

The birds were placed in a brick house with concrete floor, a lateral wall of $40 \mathrm{~cm}$ and wire mesh roof. It has a mobile curtain system, a temperature control system with fans and sprinklers, and a oven heating system. There were 48 boxes of $3.90 \times 1.50$ meters, located in the central region of the house (aviary), with capacity of 70 birds each. The feeders were the tubular type and the water drinkers were the pendulum type. In this experiment, 3,360 male chickens Cobb breed were used, half of which were from 34 weeks old broiler breeders headquarters and the other half from half 57 weeks old broiler breeders.

Two basal, isoproteic, isoaminoacidic, and isoenegetic meal diets were formulated as described by Rostagno et al. (2005). The first one was a traditional diet based on corn and soybean, and the second diet was formulated with $100 \%$ of sorghum. Both the diets were divided in the initial phase (from 0 to 21 days old) (Table 1) and growth phase (from 22 to 42 days old) (Table 2). The experimental diets had been produced by the unit Rações do Abatedouro Coroaves LTDA and the feed ingredients used were submitted to the quality control adopted from the company, involving the classification of grains, crude protein analyses, soluble protein, ether extract, crude fiber, ashes (ANFAR, 1998), tannin analysis (Nutron Alimentos LTDA), and aflatoxin levels dosage through commercial kit $\left(\right.$ RIDASOFT $\left.^{\circledR}\right)$ with a 450 nm filter density optic reader (ELX-800).

Table 1 - Centesimal and calculated composition of experimental diets for broilers from 1 to 21 days.

\begin{tabular}{|c|c|c|c|c|c|c|}
\hline \multirow{3}{*}{ Ingredients $\%$} & \multicolumn{6}{|c|}{ Ration } \\
\hline & \multirow{2}{*}{ Corn } & \multicolumn{5}{|c|}{ Sorghum and Yeast wall (YW - \%) } \\
\hline & & $0 \mathrm{YW}$ & $0.1 \mathrm{YW}$ & $0.2 \mathrm{YW}$ & $0.3 \mathrm{YW}$ & $0.4 \mathrm{YW}$ \\
\hline Corn & 53.07 & - & - & - & - & - \\
\hline Sorghum & - & 53.93 & 53.93 & 53.93 & 53.93 & 53.93 \\
\hline Soybean meal & 28.63 & 32.43 & 32.43 & 32.43 & 32.43 & 32.43 \\
\hline Full-Fat soybean & 13.80 & 9.17 & 9.17 & 9.17 & 9.17 & 9.17 \\
\hline Aderex & 0.25 & 0.30 & 0.20 & 0.20 & 0.20 & 0.20 \\
\hline Caulin & 0.40 & 0.40 & 0.30 & 0.20 & 0.10 & - \\
\hline Limestone & 0.97 & 0.97 & 0.97 & 0.97 & 0.97 & 0.97 \\
\hline Dicalcium phosphate & 1.63 & 1.60 & 1.60 & 1.60 & 1.60 & 1.60 \\
\hline Salt & 0.49 & 0.50 & 0.50 & 0.50 & 0.50 & 0.50 \\
\hline L-lysine $\mathrm{HCl} 30 \%$ & 0.38 & 0.40 & 0.40 & 0.40 & 0.40 & 0.40 \\
\hline Methionine $99 \%$ & 0.23 & 0.25 & 0.25 & 0.25 & 0.25 & 0.25 \\
\hline Mineral supplement & 0.05 & 0.05 & 0.05 & 0.05 & 0.05 & 0.05 \\
\hline Vitamin supplement & 0.10 & 0.10 & 0.10 & 0.10 & 0.10 & 0.10 \\
\hline Yeast wall & - & - & 0.10 & 0.20 & 0.30 & 0.40 \\
\hline Total & 100 & 100 & 100 & 100 & 100 & 100 \\
\hline \multicolumn{7}{|l|}{ Calculated composition } \\
\hline Crude protein $\%$ & 23.05 & 23.26 & 23.26 & 23.26 & 23.26 & 23.26 \\
\hline Metabolizable energy $\mathrm{kcal} / \mathrm{kg}$ & 3,050 & 3,050 & 3,050 & 3,050 & 3,050 & 3,050 \\
\hline Digestible lysine $\%$ & 1.19 & 1.19 & 1.19 & 1.19 & 1.19 & 1.19 \\
\hline Digestible met + cys $\%$ & 0.84 & 0.84 & 0.84 & 0.84 & 0.84 & 0.84 \\
\hline Digestible tryptophan $\%$ & 0.26 & 0.27 & 0.27 & 0.27 & 0.27 & 0.27 \\
\hline Digestible threonine $\%$ & 0.77 & 0.77 & 0.77 & 0.77 & 0.77 & 0.77 \\
\hline
\end{tabular}

Mineral supplement (1 kg): Copper: 20,000 mg; Iodine: 2,000 mg; Iron: 100,000 mg; Manganese: 160,000 mg; Zinc:100,000 mg. Vitaminic supplement (1 kg): vit A: 8,000,000 IU; vit D3: 2,000,000 IU; vit E: 14,500 IU; vit K3: 1,900 mg; vit B1: 1,333 mg; vit B2: 5,750 mg; vit B6: 2,380 mg; vit B12: $11 \mathrm{mg}$; Biotin: $30 \mathrm{mg}$; Folic acid: $760 \mathrm{mg}$; Nicotinic acid: 23,800 mg; Pantothenic acid: 11,400 mg; Selenium: $220 \mathrm{mg}$. 
Table 2 - Centesimal and calculated composition of experimental diets for broilers from 22 to 42 days.

\begin{tabular}{|c|c|c|c|c|c|c|}
\hline \multirow{3}{*}{ Ingredients $\%$} & \multicolumn{6}{|c|}{ Ration } \\
\hline & \multirow{2}{*}{ Corn } & \multicolumn{5}{|c|}{ Sorghum and Yeast wall (YW - \%) } \\
\hline & & $0 \mathrm{YW}$ & $0.1 \mathrm{YW}$ & $0.2 \mathrm{YW}$ & $0.3 \mathrm{YW}$ & $0.4 \mathrm{YW}$ \\
\hline Corn & 56.53 & - & - & - & - & - \\
\hline Sorghum & - & 58.57 & 58.57 & 58.57 & 58.57 & 58.57 \\
\hline Soybean meal & 19.67 & 27.73 & 27.73 & 27.73 & 27.73 & 27.73 \\
\hline Full-Fat soybean & 19.40 & 9.33 & 9.33 & 9.33 & 9.33 & 9.33 \\
\hline Aderex & 0.25 & 0.23 & 0.23 & 0.23 & 0.23 & 0.23 \\
\hline Caulin & 0.40 & 0.40 & 0.30 & 0.20 & 0.10 & - \\
\hline Limestone & 0.93 & 0.93 & 0.93 & 0.93 & 0.93 & 0.93 \\
\hline Dicalcium phosphate & 1.50 & 1.47 & 1.47 & 1.47 & 1.47 & 1.47 \\
\hline Salt & 0.47 & 0.48 & 0.48 & 0.48 & 0.48 & 0.48 \\
\hline L-lysine $\mathrm{HCl} 30 \%$ & 0.48 & 0.47 & 0.47 & 0.47 & 0.47 & 0.47 \\
\hline Methionine $99 \%$ & 0.22 & 0.24 & 0.24 & 0.24 & 0.24 & 0.24 \\
\hline Mineral supplement & 0.05 & 0.05 & 0.05 & 0.05 & 0.05 & 0.05 \\
\hline Vitamin supplement & 0.10 & 0.10 & 0.10 & 0.10 & 0.10 & 0.10 \\
\hline Yeast wall & - & - & 0.10 & 0.20 & 0.30 & 0.40 \\
\hline Total & 100 & 100 & 100 & 100 & 100 & 100 \\
\hline \multicolumn{7}{|l|}{ Calculated composition } \\
\hline Crude protein $\%$ & 21.39 & 21.61 & 21.61 & 21.61 & 21.61 & 21.61 \\
\hline Metabolizable energy $\mathrm{kcal} / \mathrm{kg}$ & 3,150 & 3,150 & 3,150 & 3,150 & 3,150 & 3,150 \\
\hline Digestible lysine $\%$ & 1.10 & 1.10 & 1.10 & 1.10 & 1.10 & 1.10 \\
\hline Digestible met + cys $\%$ & 0.79 & 0.79 & 0.79 & 0.79 & 0.79 & 0.79 \\
\hline Digestible tryptophan $\%$ & 0.23 & 0.25 & 0.25 & 0.25 & 0.25 & 0.25 \\
\hline Digestible threonine $\%$ & 0.71 & 0.71 & 0.71 & 0.71 & 0.71 & 0.71 \\
\hline
\end{tabular}

Mineral supplement (1 kg): Copper: 20,000 mg; Iodine: 2,000 mg; Iron: 100,000 mg; Manganese: 160,000 mg; Zinc:100,000 mg. Vitaminic supplement (1 kg): vit A: 8,000,000 IU; vit D3: 2,000,000 IU; vit E: 14,500 IU; vit K3: 1,900 mg; vit B1: 1,333 $\mathrm{mg}$; vit B2: 5,750 mg; vit B6: 2,380 mg; vit B12: $11 \mathrm{mg}$; Biotin: $30 \mathrm{mg}$; Folic acid: $760 \mathrm{mg}$; Nicotinic acid: 23,800 mg; Pantothenic acid: 11,400 mg; Selenium: $220 \mathrm{mg}$.

The experimental birds had been vaccinated on the $1^{\text {st }}$ day at hatchery against Marek Disease and Infectious Bursal Disease (combined), and Infectious Bronchitis in spray (MASS-I $\left.{ }^{\circledR}\right)$. On the $7^{\text {th }}$ and $14^{\text {th }}$ day, they were vaccinated against the Infectious Bursal Disease in water (Bursine Plus ${ }^{\circledR}$ ), and on the $14^{\text {th }}$ day they were vaccinated against NewCastle Disease in water (Poulvac NDW ${ }^{\circledR}$ enterotropic). All vaccines were alive and attenuated.

The experiment was totally randomized with a $2 \times 5$ design, with two broiler breeders ages ( 34 and 57 weeks) and five yeast wall supplementation levels (zero, one, two, three or four $\mathrm{kg} / \mathrm{ton}$ ), and two control diets (corn and soybean meal). Each treatment had four repetitions, with 70 birds each. The average composition of the yeast wall was $30 \%$ of protein (maximum), $3.0 \%$ of crude fiber (maximum), $6.9 \%$ of ashes (maximum), aflatoxin absence and $25 \%$ of manna oligosaccharides and $30 \%$ of $\beta$-glucans.

For the evaluation of zootechnical parameters, the birds were weighed at the time of delivery in the aviary and then weighed weekly at 7 am before feeding until $42^{\text {th }}$ day. The diets left overs were weighed on day 7, 14, 21, 28, 35 and 42. Based on these data, average weight gain and feed conversion were calculated.

On day 42, three broilers of each repetition were weighed and sent in cages to the slaughterhouse. In the pre-slaughter period, the broilers were kept in a platform with a forced ventilation and humidification systems to minimize the stress conditions. The slaughter process was followed by hanging, stunting, automatic bleeding (the company worked with humanitarian slaughter control), picking, and manual evisceration. After the evisceration, the birds were directed to the cutting room, where they underwent to an evaluation of carcass yield and were considered the weight of the eviscerated carcass (without viscera, neck, head and feet).

Two broilers of each repetition were used for the evaluation of the phagocytic activity of macrophages, totalizing four birds for the treatment. The broilers were inoculated on the $38^{\text {th }}$ 
day of life, through Sephadex G-50 ${ }^{\circledR}$ (Sigma) 3\% intra-abdominal injection, (one $\mathrm{mL} / 100 \mathrm{~g}$ of live weight) (Qureshi et al., 1986; Gore and Qureshi, 1997; Konjufca, 2004). Intravascular catheters G14 were used for this. Forty two hours after the inoculation, the broilers were stunted by eletronarcosis and sacrificed through cervical disconnection. Before collecting the abdominal fluid, the broilers skin was washed with neutral detergent and decontaminated with $70 \%$ alcohol. At the laboratory, each abdominal fluid sample was washed with $20 \mathrm{~mL}$ of sterile PBS + heparine solution (contends $0,5 \mathrm{UI} / \mathrm{mL}$ of Liquemine ${ }^{\circledR}$ 25,000 UI/5mL - Roche).

Approximately $15 \mathrm{~mL}$ of abdominal liquid of each broiler was collected with Pasteur pipettes and immediately conditioned in Falcon pipes in ice bath. All the samples were centrifuged at $1500 \mathrm{x} \mathrm{g}$ for 10 minutes and the pellet was resuspended in 2 $\mathrm{mL}$ of RPMI $1640^{\circledR}$ solution (Sigma). One hundred and fifty microliter of this suspension was added to each well of the culture plate ( 24 wells), with a $13 \mathrm{~mm}$ diameter glass slide. The culture plates were incubated at room temperature for one hour. Each plate was washed by sterile cooled PBS to remove the not adherent cells. After that, 150 $\mu \mathrm{L}$ of RPMI $1640^{\circledR}$ solution (Sigma) with $3 \%$ of sheep erythrocytes was added and the plates were incubated at room temperature in a 5\% of carbonic gas atmosphere for one hour. Once again the cooled PBS solution was used to remove the not adherent sheep erythrocytes. After that, the staining was performed using a commercial kit (Panótico Fast LB ${ }^{\circledR}$ - Laborclin). After 24 h, the glass slides were embedded using Permount ${ }^{\circledR}$. Three hundred macrophages were counted in each glass slide and also the number of the cells that contained engulfed sheep erythrocytes. The phagocytic activity was calculated considering the number of macrophages with engulfed erythrocytes divided by the total number of counted macrophages.

The average weight, feed conversion, average weight and yield of the cuts were submitted to polynomial regression analysis admitting normal distribution and identity link function (Interactive Data Analysis - SAS, 2000). The phagocytic activity was submitted to the regression analysis admitting gamma distribution and identity link function (Interactive Dates Analysis - SAS, 2000).The Dunnett test was adopted for comparison of the control diet (corn) with the other treatments (SAS, 2000).

\section{RESULTS AND DISCUSSION}

The age of the broiler breeder affected the weight of commercial cuts $(\mathrm{P} \leq 0.05)$; however, considering the cuts yield, this effect was not observed $(\mathrm{P}>0.05)$. Regression analysis showed no influence of the levels of inclusion of yeast wall $(\mathrm{P}>0.05)$ on the average weight of the broilers and had also no improvement in the feed conversion using sorghum and yeast wall and the corn control diet (Table 3). There was no difference among the treatments for the young chickens derived from breeders of 34 weeks old for average weight at 21 and 42 days $(P>0.05)$.

The feed conversion was better for the corn based diet $(\mathrm{P} \leq 0.05)$ at 21 days. However, at 42 days, the feed conversion of the corn based diet showed no difference $(\mathrm{P}>0.05)$ with the treatments with sorghum and 2 or $4 \mathrm{~kg} / \mathrm{ton}$ of yeast wall. Treatments of the sorghum based diet and 1 or 3 $\mathrm{kg} / \mathrm{ton}$ of yeast wall showed worse feed conversion (Table 03).

For the progeny arrays of 57 weeks old, it was observed that chickens at 21 days with corn based diet had better average age $(\mathrm{P} \leq 0.05)$ than those with sorghum based diet and yeast wall, except for the treatment with the supplementation of $4 \mathrm{~kg} / \mathrm{ton}$ of yeast wall $(\mathrm{P}>0.05)$ (Table 3$)$. There was no difference among the treatments for average weight at 42 days $(\mathrm{P}>0.05)$.

The feed conversion at 21 days was better for the corn based diet when compared with sorghum and yeast wall $(\mathrm{P} \leq 0.05)$. However, at 42 days, the corn diet and the sorghum diet with $4 \mathrm{~kg} / \mathrm{ton}$ of yeast wall showed similar results $(\mathrm{P}>0,05)$ and were better $(\mathrm{P} \leq 0.05)$ than the other treatments. In the studies carried out by Rutz et al. (2006), improvements in the feed conversion had been observed when the broilers received $2 \%$ of yeast extract at the first week and between 38 and 42 days, which was attributed to the inositol and nucleotides present in the yeast extract. 
Table 3 - Means and standard errors of average weight (AW) and feed conversion (FC) at 21 and 42 days for broilers hatched from breeders with 34 and 57 weeks old fed with different levels of yeast wall (YW) supplementation in a sorghum diet compared to a controlled diet.

\begin{tabular}{lcccc}
\hline \multirow{2}{*}{ Diet } & \multicolumn{4}{c}{ 30 weeks broiler breeders } \\
\cline { 2 - 5 } & AW 21 days $(\mathrm{kg})$ & AW 42 days $(\mathrm{kg})$ & FC 21 days $(\mathrm{kg})$ & FC 42 days $(\mathrm{kg})$ \\
\hline Corn & $0.864^{\mathrm{a}} \pm 0.005$ & $2.491^{\mathrm{a}} \pm 0.025$ & $1.33^{\mathrm{a}} \pm 0.005$ & $1.94^{\mathrm{a}} \pm 0.033$ \\
Zero YW & $0.833^{\mathrm{a}} \pm 0.008$ & $2.518^{\mathrm{a}} \pm 0.019$ & $1.39^{\mathrm{b}} \pm 0.009$ & $1.99^{\mathrm{a}} \pm 0.023$ \\
$1 \mathrm{~kg} /$ ton YW & $0.840^{\mathrm{a}} \pm 0.006$ & $2.473^{\mathrm{a}} \pm 0.010$ & $1.42^{\mathrm{b}} \pm 0.008$ & $2.04^{\mathrm{b}} \pm 0.017$ \\
$2 \mathrm{~kg} /$ ton YW & $0.830^{\mathrm{a}} \pm 0.007$ & $2.494^{\mathrm{a}} \pm 0.038$ & $1.39^{\mathrm{b}} \pm 0.010$ & $2.00^{\mathrm{a}} \pm 0.005$ \\
$3 \mathrm{~kg} /$ ton YW & $0.839^{\mathrm{a}} \pm 0.007$ & $2.470^{\mathrm{a}} \pm 0.014$ & $1.42^{\mathrm{b}} \pm 0.029$ & $2.02^{\mathrm{b}} \pm 0.016$ \\
$4 \mathrm{~kg} /$ ton YW & $0.827^{\mathrm{a}} \pm 0.015$ & $2.486^{\mathrm{a}} \pm 0.013$ & $1.41^{\mathrm{b}} \pm 0.011$ & $2.00^{\mathrm{a}} \pm 0.011$ \\
\hline & \multicolumn{5}{c}{57 weeks broiler breeders } & $1.97^{\mathrm{a}} \pm 0.018$ \\
\hline Corn & $0.938^{\mathrm{a}} \pm 0.005$ & $2.655^{\mathrm{a}} \pm 0.014$ & $1.31^{\mathrm{a}} \pm 0.032$ & $2.05^{\mathrm{b}} \pm 0.027$ \\
Zero YW & $0.883^{\mathrm{b}} \pm 0.010$ & $2.536^{\mathrm{a}} \pm 0.018$ & $1.38^{\mathrm{b}} \pm 0.008$ & $2.09^{\mathrm{b}} \pm 0.013$ \\
$1 \mathrm{~kg} /$ ton YW & $0.896^{\mathrm{b}} \pm 0.010$ & $2.575^{\mathrm{a}} \pm 0.035$ & $1.41^{\mathrm{b}} \pm 0.015$ & $2.05^{\mathrm{b}} \pm 0.011$ \\
$2 \mathrm{~kg} /$ ton YW & $0.893^{\mathrm{b}} \pm 0.012$ & $2.581^{\mathrm{a}} \pm 0.006$ & $1.39^{\mathrm{b}} \pm 0.013$ & $2.04^{\mathrm{b}} \pm 0.008$ \\
$3 \mathrm{~kg} /$ ton YW & $0.875^{\mathrm{b}} \pm 0.014$ & $2.541^{\mathrm{a}} \pm 0.010$ & $1.40^{\mathrm{b}} \pm 0.018$ & $2.02^{\mathrm{a}} \pm 0.020$ \\
4kg/ton YW & $0.909^{\mathrm{a}} \pm 0.009$ & $2.629^{\mathrm{a}} \pm 0.030$ & $1.39^{\mathrm{b}} \pm 0.010$ &
\end{tabular}

Different words at same column differ from control (Dunnett) $(\mathrm{P} \leq 0.05)$.

The average weight results of this study differed from Hooge (2004) who found positive effect of the manna oligosaccharides on the weight and feed conversion of the broilers when compared with a traditional diet without antibiotics. When compared with the diet with growth-promoter antibiotics, the author observed that the diet containing manna oligosaccharides had similar results. The findings of Zhang et al. (2005) showed that broilers at 35 days old that had received diets with $0.3 \%$ of yeast wall and $0.5 \%$ of yeast had higher weight than the control diet.

In the studies carried out with turkeys, Ferket et al. (2002) compared the use of the manna oligosaccharides and antibiotics and did not observe distinct effect between the tested antibiotics and the manna oligosaccharides. The effects observed could be considered a bit conclusive. However, under the experimental conditions, where the environment is quite favorable and the challenge to the digestive tract of the broilers is minimized, the use benefits of the yeast wall can be masked (Ferket et al., 2002).

Waldroup et al. (2003) reported that the manna oligosaccharides derived from Saccharomyces cerevisiae were promising in the suppression of gut pathogens, modulation of the immune system, promotion of the intestine integrity and improvement of the performance (feed conversion and weight gain) of turkeys and broilers. Spring et al. (2000) also observed reduction of Salmonella $s p$ in the digestive tract of birds treated with $4 \mathrm{~g}$ of oligosaccharides $/ \mathrm{kg}$. This effect is possibly related with the adsorption of the bacteria.

Fernandes et al. (2002) and Garcia (2005) had not observed disadvantages in substituting the corn by sorghum in the feed conversion, effect justified between its nutritional values, which led to assume that the variations observed in the values of feed conversion occurred randomly. Iji and Tievy (1998) demonstrated that the supplementation with manna oligosaccharides ( $1 \mathrm{~g} / \mathrm{kg}$ of feed) resulted in increased weight gain and improved the feed conversion. However, when the inclusion levels increased $(5 \mathrm{~g} / \mathrm{kg}$ of feed), the same happened to the viscosity of the ingesta, showing no benefit in the performance of the broilers.

The increasing levels of yeast wall exhibited no effect in the values for gross weight of cuts, nor in its yield in relation with the carcass for the descending lineages of the progenies offspring of 34 and 57 weeks $(\mathrm{P}>0.05)$. Comparing the sorghum based diets, supplemented with or without yeast wall, with the corn based diet, there were no differences $(\mathrm{P}>0.05)$ in the weights of the cuts (chest, whole leg, whole wing and back Table 04). These results were obtained even for gross weight and cut yield in relation to the carcass weight. Similar results were found by Rutz et al. (2006) that used yeast extract (inclusion of 2\%). The equivalence observed in the results for gross weight and cut yield for the broilers of the same breeders line and gender were in agreement with the results of Murakami et al. (1995) who 
observed differences in the yield of cuts between the strains (Cobb and Ross). In the case of gender, Stringhini et al. (2003) found greater carcass weight in the males.

The production of cuts, particularly the noble cuts, chest, thigh, and leg, is considered quite important in the poultry industry, and it is evidenced by Brazil's export of $260,630,815 \mathrm{~kg}$ of chicken cuts between January and August of 2005 to the Japanese market (APA, 2006). This clearly shows the potential of the export market in absorbing the production. In this context, the possibility to use the yeast wall for the weight gain and consequently increasing the production of more meat should be studied and optimized (Ferket et al., 2002; Hooge, 2004).

Table 4 - Means and standard errors for commercial cuts average weigth (g) and carcass yield (\%) for broilers hatched from breeders with 34 and 57 weeks old fed with different levels of yeast wall (YW) supplementation in a sorghum diet compared to a controlled diet

\begin{tabular}{|c|c|c|c|c|c|c|c|c|c|c|}
\hline \multirow[t]{3}{*}{ Diet } & \multicolumn{2}{|c|}{ Carcass } & \multicolumn{2}{|c|}{ Breast } & \multicolumn{2}{|c|}{ Whole Legs } & \multicolumn{2}{|c|}{ Whole Wing } & \multicolumn{2}{|c|}{ Back } \\
\hline & $\mathrm{Kg}$ & $\%$ & $\mathrm{~g}$ & $\%$ & $\mathrm{~g}$ & $\%$ & $\mathrm{~g}$ & $\%$ & $\mathrm{~g}$ & $\%$ \\
\hline & & & \multicolumn{8}{|c|}{34 weeks broiler breeders) } \\
\hline Corn & 1.893 & 75.99 & $678 \pm 22$ & 35.81 & $581 \pm 19$ & 30.69 & $224 \pm 07$ & 11.83 & $410 \pm 17$ & 21.66 \\
\hline Zero YW & 1.871 & 74.31 & $696 \pm 22$ & 37.20 & $562 \pm 19$ & 30.04 & $224 \pm 07$ & 11.97 & $389 \pm 17$ & 20.79 \\
\hline $1 \mathrm{~kg} /$ ton YW & 1.846 & 74.65 & $666 \pm 22$ & 36.08 & $547 \pm 19$ & 29.63 & $221 \pm 07$ & 11.97 & $412 \pm 17$ & 22.32 \\
\hline $2 \mathrm{~kg} /$ ton $\mathrm{YW}$ & 1.771 & 71.01 & $671 \pm 22$ & 37.89 & $520 \pm 19$ & 29.36 & $212 \pm 07$ & 11.97 & $368 \pm 17$ & 20.78 \\
\hline $3 \mathrm{~kg} /$ ton YW & 1.958 & 79.23 & $704 \pm 22$ & 35.95 & $577 \pm 19$ & 29.47 & $238 \pm 07$ & 12.15 & $439 \pm 17$ & 22.42 \\
\hline 4kg/ton YW & 1.825 & 73.41 & $655 \pm 22$ & 35.89 & $550 \pm 19$ & 30.14 & $218 \pm 07$ & 11.94 & $402 \pm 17$ & 22.03 \\
\hline Diet & & & \multicolumn{8}{|c|}{57 weeks broiler breeders } \\
\hline Corn & 1.952 & 73.52 & $714 \pm 27$ & 36.58 & $595 \pm 20$ & 30.48 & $231 \pm 08$ & 11.83 & $412 \pm 15$ & 21.11 \\
\hline Zero YW & 1.995 & 78.67 & $732 \pm 27$ & 36.69 & $606 \pm 20$ & 30.37 & $237 \pm 08$ & 11.88 & $420 \pm 15$ & 21.05 \\
\hline $1 \mathrm{~kg} / \mathrm{ton} \mathrm{YW}$ & 1.994 & 77.44 & $730 \pm 27$ & 36.61 & $589 \pm 20$ & 29.54 & $238 \pm 08$ & 11.93 & $437 \pm 15$ & 21.91 \\
\hline $2 \mathrm{~kg} /$ ton YW & 1.871 & 72.10 & $695 \pm 25$ & 37.34 & $573 \pm 18$ & 30.79 & $222 \pm 07$ & 11.93 & $371 \pm 14$ & 19.93 \\
\hline $3 \mathrm{~kg} /$ ton YW & 1.883 & 74.10 & $695 \pm 25$ & 36.91 & $567 \pm 18$ & 30.11 & $225 \pm 07$ & 11.95 & $396 \pm 14$ & 21.03 \\
\hline $4 \mathrm{~kg} /$ ton YW & 1.985 & 75.50 & $760 \pm 25$ & 38.29 & $587 \pm 18$ & 29.57 & $236 \pm 07$ & 11.89 & $402 \pm 14$ & 20.25 \\
\hline
\end{tabular}

Some authors have described that the component of the yeast wall, such as the manna oligosaccharides, act by the mechanisms that involve the adsorption of pathogens in the alimentary system, in particular those that present type 1 fimbriae (Spring et al., 2000), and would help to uniform and improve the villus integrity. Lowry et al. (2005) had observed that the Bglucan, present in the yeast walls, reduced the invasion capacity of enteric Salmonella serovar Enteritidis in young chickens tissues (one week old), and as a consequence provided better immunity, better weight gain and, possibly, better exploitation of cuts. However, in the present study, such obervations were not made.

The age of the breeders did not show any effect on the fagocytic activity of macrophages, characterized by the phagocytosis of sheep erythrocytes, stimulated through the abdominal injection of Sephadex G-50 ${ }^{\circledR}$ (Sigma) $(\mathrm{P}>0.05)$. It was considered that, under the aspect innate immunity, the breeders age did not benefit the offspring. However, factors related to the genetic lines had demonstrated differences between the macrophages functions (Qureshi and Miller, 1991).

The results demonstrated that the activity of the macrophages was influenced in a quadratic form $\left(\mathrm{Y}=0.1297+0.1143 \mathrm{PL}-0.0278 \mathrm{PL}^{2}\right)$ with $\mathrm{a}$ maximum point for inclusion of $2.06 \mathrm{~kg}$ of yeast wall/ton (Table 5). In comparison (Dunnett test) with the corn based diet (control), the treatment with sorghum and $2 \mathrm{~kg}$ of yeast wall/ton presented greater number of macrophages in active fagocytosis process (engulfed erythrocytes). The other treatments showed no difference from the corn based diet. 
Table 5 - Means and standard errors of macrophage activity.

\begin{tabular}{lc}
\hline Diet & Macrophages with erythrocytes/Counted macrophages \\
\hline Corn & $14.88 \pm 5.29^{\mathrm{b}}$ \\
Zero YW & $12.19 \pm 8.98^{\mathrm{b}}$ \\
$1 \mathrm{~kg} / \mathrm{ton} Y W$ & $23.71 \pm 4.23^{\mathrm{b}}$ \\
$2 \mathrm{~kg} /$ ton YW & $31.33 \pm 8.58^{\mathrm{a}}$ \\
$3 \mathrm{~kg} /$ ton YW & $23.09 \pm 8.66^{\mathrm{b}}$ \\
$4 \mathrm{~kg} /$ ton YW & $17.83 \pm 3.57^{\mathrm{b}}$ \\
\hline
\end{tabular}

1 YW: Yeast Wall; Different words at same column differ from control (Dunnett) $(\mathrm{P} \leq 0.05)$. Quadratic response in sorghum treatments $\mathrm{Y}=0,1297+0,1143 \mathrm{YW}-0,0278 \mathrm{YW}^{2}$

The macrophages are cells of the monocuclear fagocytic system (McCorkle, 1998), integrant of the innate immunity of the broilers, and also important for the adaptative immunity (Qureshi, 2003; Abbas et al., 2007), acting in the organism defense processes by the destruction of antigens and secreting cytokines that act in the inflammatory process. The main functions executed for this cell are fagocytosis, destruction of bacteria (Qureshi et al., 1986), secretion of prostaglandins and cytokines, and antigen presentation for development of the immune response (Abbas et al., 2007). The B-glucans, present in the composition of the yeast wall, have revealed importance in the stimulation of macrophages in fish by the action of specific receptors presents in these cells (Bartelme, 2006). In general, the purified B-glucans demonstrate good activity in stimulating the cellular defense system, especially the neutrophils in the humans (LeBlanc et al., 2006) and fishes (Palic et al., 2006), and macrophages in fishes (Falcon, 2007) and mammals (Adachi, 2004). These composites bind to unspecific immune system cells (macrophages) through portion receptors of the $\beta$ 1-3 or B-1-6. As they are considered the first line of defense (Qureshi, 1998), the activation and fagocytic activity of the macrophages, if adequately stimulated, tends to supply better conditions for the broilers to engulf and to destroy the pathogens.

In the current situation of the poultry industry and looking towards the near future, the market scenraion requires reduction in the use of the antibiotics. This requires search for immune modulators that do not leave residues in the meat, promote good growth performance and works in adverse conditions so that the broilers can defend themselves against the pathogens (Dietert and Golemboski, 1998).

\section{CONCLUSIONS}

In conclusion, the breeders age influenced the growth performance; however it did not influence the macrophages activity. The sorghum could be used without any losses to the weight of the commercial cuts. However, the 57 weeks old progeny showed reduced performance on sorghum based diets. The best level of yeast wall for attaining the maximum macrophage activity of was $2.06 \mathrm{~kg} / \mathrm{ton}$ of food.

\section{REFERENCES}

Abbas, A. K.; Lichtman, A. H.; Pillai, S. (2007) Cellular and molecular immunology. $6^{\mathrm{a}}$. ed. Philadelphia: Saunders Elsevier, 566 p.

Adachi, Y.; Ishii, T.; Ikeda, Y; Hoshino, A.; Tamura, H.; Aketagawa, J.; Tanaka, S.; Ohno, N. (2004) Characterization of $\beta$-glucan recognition site on $\mathrm{C}$ type lectin, D. Infect Immun, 72, 4159-4171.

ANFAR (1998) Compêndio Brasileiro de Alimentação Animal. São Paulo: Sindirações ANFAR CBNA SDRMA, 197p.

APA - Associação Paulista de Avicultura. Exportação de carne de frango, www.apa.com.br, (Acesso em 20/12/2006).

Bartelme, T. (2003) Beta glucan as a biological defense modulator: helping fish to help themselves, september. Advanced Aquarist's On Line Magazine, www.advancedaquarist.com. Acesso em 23/02/2006.

Dietert, R. R.; Golemboski, K. A. (1998) Avian macrophage metabolism, Poult Sci, 77, 990-997.

Falcon, D. R. (2007) B-glucano e vitamina C no desempenho produtivo e parâmetros fisiopatológicos em juvenil de tilápia do Nilo: nível de suplementação e tempo de administração. Jaboticabal: Universidade Estadual Paulista - Faculdade de Ciências Agrárias e Veterinárias, 2007. 146 p. Tese (Doutorado em Aquiicultura) - Faculdade de Ciências Agrárias e Veterinárias. 
Ferket, P. R.; Parks, C. W.; Grimes, J. L., (2002) Benefits of dietary antibiotic and mannanoligosaccharide supplementation for poultry. In: MULTI-STATE POULTRY MEETING, 2002, Indianapolis. Proceedings...Indianapolis: University of Illinois, p.22.

Garcia, R. G. (2005) Aspectos produtivos e qualitativos da utilização de sorgo na alimentação de frangos de corte. Botucatu: Universidade Estadual Paulista, 2005. 126 p. Tese (Doutorado em Zootecnia) Universidade Estadual Paulista.

Gore, A. B.; Qureshi, M. A. (1997) Enhancement of humoral and cellular immunity by vitamin $\mathrm{E}$ after embryonic expousure. Poult Sci, 76, 984-991

Hooge, D. M. (2004) Meta-analysis of broiler chicken pen trials evaluating dietary mannan oligosaccharide, 1993-2003. Int J Poult Sci, 3, 163-174.

Iji, P. A.; Tivey, D. R. (1998) Natural and synthetic oligosaccharides in broiler chicken diets. World Poultry Sci J, 54, 129-143.

Konjufca, V. K. (2004) Influence of dietary vitamin E on phagocytic functions of macrophages in broilers. Poult Sci, 83, 1530-1534.

Leblanc, B. W.; Albina, J. E.; Reichner, J. S. (2006) The effect of PGG- $\beta$-glucan on neutrophil chemotaxis in vitro. J Leukocyte Biol, 79, 667-675.

Lowry, V.K.; Farnell, M.B.; Ferro, P.J.; Swaggerty, C.L.; Bahl, A.; Kogut, M.H. (2005) Purified betaglucan as an abiotic feed additive up-regulates the innate immune response in immature chickens against Salmonella enterica serovar Enteritidis. Poult Sci, 98, 309-318.

Mccorckle, F. M. (1998) Introduction to the symposium: nonlymphoid cells and their factors in immune response. Poult Sci, 77, 963.

Murakami, A. E.; Nerilo, N.; Furlan, A. C.; Scapinello, C. ; Barbosa, M. J. B. (1995) Desempenho, rendimento de carcaça, cortes e desossa de três linhagens comerciais de frangos de corte. In: Conferência Apinco de Ciência e Tecnologia Avícolas, Curitiba. Trabalhos de pesquisa, Campinas: FACTA, p.279-280.

Palic, D.; Andreasen, C. B.; Herolt D. M.; Menzel, B. W.; Roth, J. A. (2006) Immunomodulatory effects of beta-glucan on neutrophil function in fathead minnows. Dev Comp Immunol, 30, 817-830.

Pucciarelli, A. B., Benassi, F. O. (2009) Inactivation of Salmonella Enteritidis on Raw poultry Using Microwave Heating. Braz Arch Biol Techn, 52, 785793.

Qureshi, M. A. (2003) Avian macrophage and immune response: an overview. Poult Sci, 82, 691-698.
Qureshi, M. A. (1998) Role of Macrophages in avian health and disease. Poult Sci, 77, 978-982.

Qureshi, M. A.; Dieteri, R. R.; Bacon, L. D. (1986) Genetic variation in the recruitment and activation of chicken peritoneal macrophages, Exp Biol Med, 181, 560-568.

Qureshi, M. A; Marsh, J. A.; Dietery, R. R.; Sung, Y. J.; Nicolas-Bolnet, C.; Petitte, J. N. (1994) Profiles of chicken macrophages effector functions. Poult Sci, 73, 1027-1034.

Qureshi, M. A; Miller, L. (1991) Comparison of macrophage functions in several commercial broiler genetic lines. Poult Sci, 70, 2094-2101.

Rostagno, H. S., Albino, L. F. T., Donzele, J. L., Gomes, P.C.; Oliveira, R. F.; Lopes, D.C.; Ferreira, A.S.; Barreto, S.L.T. Tabelas brasileiras para aves e suínos - Composição de alimentos e exigências nutricionais. Viçosa: UFV, Departamento de Zootecnia, 2005. 186p.

Rutz,F.; Anciut, M.A.; Rech, J.L.; Gonçalves, F.M.; Delgado, A.D.; Rosa, E.R.; Zauk, N.; Ribeiro, C.L.G.; Silva, R.R.; Dallmann, P.R. (2006) Desempenho e características de carcaças de frangos de corte recebendo extrato de leveduras na dieta. Cienc Anim Bras, 7, 349-355.

SAS Institute Inc., Statistical Analysis System, Versão 8.0. Cary, NC: 2000.

Soares, A. L.; Olivo, R.; Shimokomaki, M.; Ida, E. I. (2004) Synergism between Dietary Vitamin E and Exogenous Phytic Acid in Prevention of WarmedOver Flavour Development in Chicken Breast Meat, Pectoralis major M. Braz Arch Biol Techn, 47, 57-62

Spring, P.; Wenk, C.; Dawson, K. A.; Newman, K. E. (2000) The effects of dietary mannanoligosaccharide on cecal parameters and the concentrations of enteric bacteria in the ceca samonella-challenged broiler chicks. Poult Sci, 79, 205-211.

Stringhini, J. H., Laboissiére, M.; Muramatsu, K.; Leandro, N.S.M.; Café, M.B. (2003) Avaliação do Desempenho e Rendimento de Carcaça de Quatro Linhagens de Frangos de Corte Criadas em Goiás. Rev Bras Zootec, 32, 183-190.

Waldroup, P. W.; Fritts, C. A.; Yan, F. (2003) Utilization of Bio-Mos ${ }^{\circledR}$ mannanoligosaccharide and Bioplex ${ }^{\circledR}$ Copper in broiler diets. Int J Poult Sci, 2, 44-52.

Zhang, A.W.; Lee, B.D.; Lee, S.K.; Lee, K.W.; An, G.H.; Song, K.B.; Lee, C.H. (2005) Effects of yeast (Saccharomyces cerevisiae) cell components on growth performance, meat quality, and illeal mucosa development of broiler chicks. Poult Sci, 84, 10151021. 